\title{
Influence of Pre-Sowing Operations on Soil-Dwelling Fauna in Soybean Cultivation
}

\author{
Darija Lemic *(D), Ivana Pajač Živković (D), Marija Posarić and Renata Bažok (D) \\ Department for Agricultural Zoology, Faculty of Agriculture, University of Zagreb, Svetosimunska 25, \\ 100000 Zagreb, Croatia; ipajac@agr.hr (I.P.Ž.); posaric2308@gmail.com (M.P.); rbazok@agr.hr (R.B.) \\ * Correspondence: dlemic@agr.hr; Tel.: +385-123-9649
}

Citation: Lemic, D.; Pajač Živković,

I.; Posarić, M.; Bažok, R. Influence of Pre-Sowing Operations on Soil-Dwelling Fauna in Soybean Cultivation. Agriculture 2021, 11, 474. https://doi.org/10.3390/ agriculture11060474

Academic Editor: Eric Blanchart

Received: 10 April 2021

Accepted: 18 May 2021

Published: 21 May 2021

Publisher's Note: MDPI stays neutral with regard to jurisdictional claims in published maps and institutional affiliations.

Copyright: (c) 2021 by the authors. Licensee MDPI, Basel, Switzerland. This article is an open access article distributed under the terms and conditions of the Creative Commons Attribution (CC BY) license (https:// creativecommons.org/licenses/by/ $4.0 /)$.

\begin{abstract}
The aim of this study was to determine the effects of different pre-sowing operations on the abundance and composition of total soil fauna in soybean cultivation, with special attention to carabids as biological indicators of agroecosystem quality. The study was conducted in central Croatia with six different pre-sowing activities (cover crop, mulching, ploughing, glyphosate, fertiliser removal, conventional tillage). Pitfall traps were used to collect soil fauna in April, June and September. After determining the abundance and composition of the fauna, their coenological characteristics were calculated and statistical analysis was performed. During the study, 7836 individuals of soil fauna were collected. The composition consisted of $84 \%$ beneficial, $8 \%$ harmful and $8 \%$ indifferent fauna. Class Insecta was the most numerous with a proportion of $56 \%$, with most members of the family Carabidae (1622 individuals), followed by the class Arachnida (40\%). The number of fauna collected was influenced by the interaction between pre-seeding intervention and sampling date. Pre-seeding interventions that did not involve soil activities did not affect the number and composition of soil fauna at the beginning of vegetation. Mechanical interventions in the soil and warmer and drier weather have a negative effect on the number and composition of soil fauna. As the season progresses, the influence of pre-sowing activities on soil fauna in soybean crops decreases. It seems that a reduction in mechanical activities in the shallow seed layer of the soil has a positive effect on species richness or diversity. Of particular note is the large proportion of beneficial insects that currently colonise the study area, characterising soil richness and stable natural equilibrium.
\end{abstract}

Keywords: soybean; pre-sowing soil activities; soil fauna; ground beetles; dominance; frequency

\section{Introduction}

Soybean (Glycine max L. Merril) is one of the oldest crops with high oil and protein content in the grain [1,2]. The protein and oil content depends on the variety and growing conditions and can vary between $35-50 \%$ protein and $18-24 \%$ soybean oil [3]. This oilseed is used in oil production, food production and animal nutrition. In the food industry, it is used in the form of soybean, oil, flour and milk, while grain, stalk or bread is used as livestock feed. However, the main reason for its cultivation is still livestock [3]. Besides its important role in human and livestock nutrition, it is also desirable in crop rotation. Through its symbiosis with nodule bacteria, it enriches the soil with nitrogen [4,5]. Soybean is a demanding crop that differs from other crops in complexity and cultivation requirements, especially in tillage and soil preparation for sowing. Basic ploughing is carried out to a depth of $30 \mathrm{~cm}$, and in heavier soils levelling must be carried out in the autumn. In early spring, the soil must be closed as early as possible to retain all accumulated moisture [6].

Frequent and intensive tillage of any crop, including soybean cultivation, results in greater soil compaction or disruption of the continuity of larger pores and corridors of organisms in the soil. Such soil affects both the abundance and diversity of soil fauna as compaction creates unfavourable living conditions, especially anaerobic conditions $[7,8]$. One of the most important components of soil, apart from its chemical and physical 
properties, is its biological component or soil organisms. The biological component or soil biodiversity is a very important but at the same time insufficiently known component of the soil ecosystem $[9,10]$. Biodiversity consists of soil organisms that spend all or part of their life cycle either in the soil or on its surface (including crop residues or mulch) and are responsible for processes that are very important for soil health and fertility [8]. Tillage is one of the most aggressive activities affecting soil biological balance. Biological balance refers to the interactions among organisms, including the structure of food webs and the ability of ecological systems to sustain themselves over time. In general, deeper and more frequent tillage increases negative impacts on soil organisms, while no-till, strip tillage and compatible tillage systems maintain biodiversity and soil organism richness in crop production. Improper and inappropriate tillage results in greater soil compaction or disruption of the continuity of larger soil pores as well as the corridors of soil organisms. This mainly affects the abundance, but also the diversity of the biological component of the soil [11], as greater soil compaction creates less favourable living and especially anaerobic conditions, which are only suitable for a smaller number of soil organisms [8].

The organisms in the soil are divided into three categories according to their influence on agriculture: Beneficial, Indifferent and Pests, and according to their size into four basic groups: Microfauna, Mesofauna, Macrofauna and Megafauna [12]. The abundance of beneficial organisms is extremely important as it is often used as an indicator to assess the viability of the agroecosystem. Higher numbers of beneficial soil organisms indicate better sustainability and positive impact on the crops grown [13]. Beneficial fauna has a positive impact on increasing soil fertility (decomposition and mineralisation of organic matter; mixing, transport and combination of organic and mineral soil components; transport of microorganisms...) and regulating the water-air ratio (creation and maintenance of soil pores) [14].

In the cultivation of soybeans, the occurrence of pests affects the quality and quantity of the grain. To prevent such damage, all available control measures are used, including chemical measures. Pesticides can be used in soybean production to control insects, mites, weeds and pathogens [15]. The use of pesticides has negative effects and destroys beneficial soil organisms $[8,16,17]$. Nietupski [18] states that of all pesticides used, only herbicides have negative effects on beneficial Carabidae.

The most numerous beneficial insects in soil fauna are species from the orders Collembola and Coleoptera, which are often referred to as bio-indicators [19]. These organisms have different feeding strategies and functional roles within soil processes. Collembola communities influence nutrient availability through their interactions with soil organisms [20], such as rates of bacterial and fungal consumption and spore transport. The relationships of soil collembolan fauna to their ecological niches and the stability of community composition at a given site provide good starting points for bioindication of changes in soil properties and impacts of human activities [21]. Carabids are often used as indicators of habitat change. They have been used in grasslands and boreal forests where species numbers and/or abundance have been found to change along a habitat disturbance gradient [22]. Their numbers are influenced by many factors, one of which is the pre-seeding procedure.

Glyphosate has been the subject of controversy for several years, ever since the World Health Organization (WHO) warned of possible carcinogenic and genotoxic effects on humans. Glyphosate is the active ingredient in many commercial herbicides, of which the best-known commercial product in the world is called Roundup, while in Croatia it is better known as Cidokor [23]. The use of glyphosate is extremely widespread in agriculture and horticulture [24]. Vandenberg et al. [25] noted that more than 1500 studies have been conducted on the safety of glyphosate in the last decade, potentially changing the regulatory view. More intensive research on the effects of glyphosate on beneficial (and harmful) soil fauna has not been conducted. Currently, there are no studies on the impact of pre-sowing intervention or glyphosate application on overall soil fauna and particularly on beneficial insects in soybean production. 
Based on all the above, the hypothesis of this study is as follows: in soybean cultivation, more intensive tillage before sowing and glyphosate application have a negative impact on the whole soil fauna and especially on the members of the beneficial fauna. Based on the hypothesis, the objective of the study was to determine the total soybean soil fauna and the effects of different pre-sowing interventions on the abundance and composition of soil fauna in soybean cultivation.

\section{Materials and Methods}

\subsection{The Locality of the Experiment}

In 2019, a survey was conducted in six localities in the area of Šašinovec $\left(45^{\circ} 51^{\prime} 00^{\prime \prime} \mathrm{N}\right.$ $\left.16^{\circ} 10^{\prime} 01^{\prime \prime} \mathrm{E}\right)$, a village near Zagreb in the central part of Croatia. Six soybean fields were sown in each of these six localities (36 soybean fields in total). In each field, different soil treatments were applied before sowing. Cover crops were sown in field 1 . Field 2 was mulched, while field 3 was ploughed. Glyphosate was applied to field 4 for weed control. Field 5 was ploughed under, and field 6 had standard tillage (stubble ploughing at $10 \mathrm{~cm}$, deep fall ploughing at $25 \mathrm{~cm}$ in 2018, and winter furrow closure and standard soil preparation for seeding in 2019). Mulching, cover plants and glyphosate applications do not involve soil activities, while ploughing, undermining and standard tillage represent interventions in shallower and/or deeper soil layers. More detailed data on tillage operations can be found in Table 1.

Table 1. Pre-sowing interventions and implementation dates.

\begin{tabular}{|c|c|c|c|c|c|c|}
\hline \multicolumn{7}{|c|}{ Variants } \\
\hline Activity & Cover Plants & Mulching & Ploughing & Glyphosate & Undermining & Standard * \\
\hline Sowing & 2 August 2018 & - & - & - & - & \\
\hline Mulching & - & 18 October 2018 & - & - & - & Plowing stubble \\
\hline Ploughing & - & 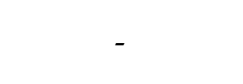 & $\begin{array}{c}12 \text { December } \\
2018\end{array}$ & - & - & $\begin{array}{l}\text { Deep ploughing } \\
\text { Furrow closing }\end{array}$ \\
\hline Glyphosate & - & - & 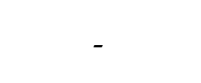 & $\begin{array}{c}3 \text { September } \\
2018\end{array}$ & - & $\begin{array}{l}\text { Pre-sowing soil } \\
\text { preparation }\end{array}$ \\
\hline Undermining & & & & & 1 August 2018 & \\
\hline $\begin{array}{l}\text { Soybean } \\
\text { sowing }\end{array}$ & 5 June 2019 & 5 June 2019 & 5 June 2019 & 5 June 2019 & 5 June 2019 & 5 June 2019 \\
\hline
\end{tabular}

${ }^{*}$ Usual interventions of the field owner = conventional tillage in soybean cultivation.

\subsection{Soil Fauna Sampling}

Soil fauna sampling was conducted on three dates, April, June, and September, from the beginning to the end of soybean cultivation. Traps were active for two weeks in each specified sampling period. Soil fauna was collected using epigeic covered pitfall traps. Polythene pots $(\varnothing=12 \mathrm{~cm}, \mathrm{~h}=18 \mathrm{~cm})$ were incorporated $18 \mathrm{~cm}$ into the soil and covered with PVC roofs $(\varnothing=16 \mathrm{~cm})$ approximately $4 \mathrm{~cm}$ above ground level. Each trap was half filled with salted water ( $20 \%$ solution) for captures conservation. Four pitfall traps were placed in each field, two at the edge and two in the middle of the plot. All collected samples were stored in plastic containers with appropriate labelling prior to determination.

\subsection{Data Analysis}

After collecting samples of fauna, further research was carried out in the laboratory of the Department Agricultural Zoology of the Faculty of Agriculture in Zagreb. The collected soil fauna from each sample was separated from the contaminants and transferred into containers with $96 \%$ alcohol. This was followed by sample identification. The determination was carried out with the help of light microscope and standard keys [26-31]. All organisms found were classified into the appropriate classes (Insecta, Arachnida, Malacostraca, Diplopoda, Chilopoda and Gastropoda). Members of the class Insecta are identified by family, genus or species. 
After determining the samples, a list of soybean soil fauna was compiled. After determining the number of soil fauna, their coenological characteristics, dominance and frequency were also determined.

Dominance is used to express the percentage of an order/family/genus/species in the total number of insects in a particular biotope. The Balogh formula was used to calculate dominance (cited in Balarin [32]):

$$
\mathrm{D}=(\mathrm{nA} / \mathrm{N}) \times 100
$$

D—dominance index; $\mathrm{nA}$ - the number of individuals caught of the same species/genus / order; $\mathrm{N}$ - the total number of individuals caught.

Based on the calculated dominance, the orders are classified into the following groups according to Tischler and Heydeman (cit. Balarin [29]) as eudominant ( $>10 \%)$; dominant (5-10\%); subdominant (1.00-4.99\%); recedent (0.5-0.99\%); subrecedent $(0.01-0.49 \%)$.

Frequency shows the exact number in which an order/family/genus/species appears on a surface within a biotope. The Balogh formula was used to calculate the frequency [32]:

$$
\mathrm{Ca}_{\mathrm{i}}=\mathrm{Ua}_{\mathrm{i}} / \Sigma \mathrm{U}_{\mathrm{i}} \times 10
$$

$\mathrm{Ca}_{\mathrm{i}}$-frequency index; $\mathrm{Ua}_{\mathrm{i}}$-number of samples with order found; $\Sigma \mathrm{U}_{\mathrm{i}}$ - total number.

According to Tischler (Balarin 1974), the obtained frequency results are divided into the following groups: euconstant (75-100\%); constant (50-75\%); accessory (25-50\%); accidental $(0.1-25 \%)$.

The data on the number of individuals belonging to different orders/classes captured in each field were analysed by analysis of variance (ANOVA) using the AOV factorial method with three factors using ARM 9 software software (Gylling Data Management, Brookings, South Dakota) [33]. The first factor was pre-sowing intervention, which was considered as a fixed factor. The second factor was sampling period and the third factor was statistical class. A Tukey post hoc test was used to determine which mean values of the variants were significantly different after a significant test result $(p<0.05)$.

In order to compare species richness among different treatments, the Shannon index (H) [34] was calculated based on the total collected individuals of different classes for each pre-sowing activity. The Shannon entropy quantifies the uncertainty (entropy or degree of surprise) associated with this prediction. It was calculated as follows:

$$
\text { Shannon Index }(H)=\sum_{i=1}^{s} p i \ln p i
$$

In the Shannon index, $p$ is the proportion $(\mathrm{n} / \mathrm{N})$ of individuals of one particular species found (n) divided by the total number of individuals found $(\mathrm{N}), \ln$ is the natural $\log , \Sigma$ is the sum of the calculations, and $s$ is the number of species.

Shannon's equitability $\left(E_{H}\right)$ has been calculated by dividing $\mathrm{H}$ by $\mathrm{H}_{\max }$ (here $\mathrm{H}_{\max }=$ $\operatorname{lnS}$ ) [35]. Equitability assumes a value between 0 and 1 with 1 being complete evenness.

The data on the number of individuals belonging to family Carabidae captured in each field were analysed by analysis of variance (ANOVA) using the AOV factorial method with two factors using ARM 9 software [33]. The first factor was pre-sowing intervention, which was considered as a fixed factor. The second factor was sampling period. To normalise the data, square root transformation of $X+0.5$ has been applied. A Tukey post hoc test was used to determine which mean values of the variants were significantly different after a significant test result $(p<0.05)$.

\section{Results and Discussion}

\subsection{Soybean Fauna Diversity}

Table 2 shows the number and composition of soil fauna of soybean collected in April, June and September 2019. A total of 7836 individuals were collected. The Insecta class 
was the most numerous with 4373 individuals, within which eight orders were identified. The most numerous order was Coleoptera with 2698 members, which accounted for $34 \%$ of the total soybean soil fauna collected. The study identified 807 individuals from the order Hymenoptera, which accounted for $10 \%$ of the total soybean soil fauna collected, especially members of the family Formicidae (712 individuals, 9.1\%). In addition, there were 466 members of the order Diptera (6\%), 241 members of the order Collembola (3\%), 72 members of the order Orthoptera (1\%), 2 members of the order Mecoptera $(0.03 \%)$, and 1 member of the order Lepidoptera $(0.01 \%)$. In addition, 86 individuals from the order Hemiptera were identified, representing only $1 \%$ of the total fauna collected. In the study of soybean fauna by Bažok et al. [36], the most numerous order was Hemiptera with 818 individuals, which accounted for $60.3 \%$ of the total fauna collected. However, their results show the composition of the fauna on the plant canopy. In addition to the class Insecta, this study also identified 3111 individuals from the class Arachnida, which accounted for $40 \%$ of the total soil fauna. Other classes were much less represented in the total catches.

Table 2. The number and composition of the soybean soil-dwelling fauna.

\begin{tabular}{|c|c|c|c|c|c|}
\hline Class & Order & Family & Genus/Species & In Total & Category \\
\hline \multirow{29}{*}{ Insecta } & Collembola & - & - & 241 & beneficial \\
\hline & \multirow{2}{*}{ Orthtoptera } & Acrididae & - & 10 & pest \\
\hline & & Gryllidae & Gryllus campestris Linnaeus, 1758 & 62 & pest \\
\hline & \multirow{12}{*}{ Hemiptera } & Miridae & - & 2 & pest \\
\hline & & Nabidae & - & 4 & beneficial \\
\hline & & Lygaeidae & - & 2 & pest \\
\hline & & Nepidae & - & 1 & pest \\
\hline & & Reduviidae & - & 9 & beneficial \\
\hline & & Coreidae & Coreus marginatus Linnaeus, 1758 & 1 & pest \\
\hline & & Pentatomidae & Rhaphigaster nebulosa Poda, 1761 & 1 & pest \\
\hline & & Pyrrhocoridae & Pyrrhocoris apterus Linnaeus, 1758 & 33 & beneficial \\
\hline & & Tingidae & Corythuca ciliata Say, 1832 & 5 & pest \\
\hline & & Aphididae & - & 7 & pest \\
\hline & & Cicadellidae & Iassus lanio Linnaeus, 1761 & 19 & pest \\
\hline & & Flatidae & - & 2 & pest \\
\hline & \multirow{14}{*}{ Coleoptera } & \multirow{14}{*}{ Carabidae } & Brachinus psophia Serville, 1821 & 181 & beneficial \\
\hline & & & Carabus coriacerus Linnaeus, 1758 & 4 & beneficial \\
\hline & & & Carabus arvensis Herbst, 1784 & 1 & beneficial \\
\hline & & & Carabus cancellatus tibiscinus Csiki, 1906 & 441 & beneficial \\
\hline & & & Carabus cancellatus dahli Heer, 1841 & 19 & beneficial \\
\hline & & & Clivina fossor Linnaeus, 1758 & 10 & beneficial \\
\hline & & & Bembidion sp. Latreille, 1802 & 68 & beneficial \\
\hline & & & Trechus quadristriatus Schrank, 1781 & 1 & beneficial \\
\hline & & & Anisodactylus signatus Panzer, 1796 & 2 & beneficial \\
\hline & & & Harpalus sp. Latreille, 1802 & 31 & beneficial \\
\hline & & & Harpalus affinis Schrank, 1781 & 88 & beneficial \\
\hline & & & Harpalus distinguendus Duftschmid, 1812 & 105 & beneficial \\
\hline & & & Harpalus rufipes De Geer, 1774 & 51 & beneficial \\
\hline & & & Harpalus neglectus Audinet-Serville, 1821 & 1 & beneficial \\
\hline
\end{tabular}


Table 2. Cont

\begin{tabular}{|c|c|c|c|c|c|}
\hline Class & Order & Family & Genus/Species & In Total & Category \\
\hline & & & Harpalus laevipes Zetterstedt, 1828 & 1 & beneficial \\
\hline & & & Anchomenus dorsalis Pontoppidan, 1763 & 46 & beneficial \\
\hline & & & Ophorus signaticornis Duftschmid, 1812 & 5 & beneficial \\
\hline & & & Poecilus cupreus Linnaeus, 1758 & 383 & beneficial \\
\hline & & & Pterostichus melas Creutzer, 1799 & 40 & beneficial \\
\hline & & & Pterostichus melanarius Illiger, 1798 & 6 & beneficial \\
\hline & & & Amara sp. Bonelli, 1810 & 138 & beneficial \\
\hline & & & - & 66 & beneficial \\
\hline & & Scarabaeidae & Teuchestes fossor Linnaeus, 1758 & 97 & beneficial \\
\hline & & Chrusomolidor & - & 1 & pest \\
\hline & & Cnrysomendae & Phyllotreta sp. & 72 & pest \\
\hline & & Nitidulidae & Glischrochilus quadrisignatus Say, 1835 & 9 & pest \\
\hline & & Tenebrionidae & Gonocephalum sp. Chevrolat, 1849 & 9 & beneficial \\
\hline & & Curculionidae & - & 9 & pest \\
\hline & & Staphylinidae & - & 382 & beneficial \\
\hline & & Cantharidae & - & 53 & beneficial \\
\hline & & Phalacridae & Olibrus sp. Erichson, 1845 & 4 & pest \\
\hline & & Coccinellidae & - & 8 & beneficial \\
\hline & & Cilobid & Silpha sp. Linnaeus, 1758 & 150 & beneficial \\
\hline & & sippmade & Nicrophorus sp. Fabricius, 1775 & 26 & beneficial \\
\hline & & Elateridae & - & 189 & pest \\
\hline & & Bostrychidae & - & 1 & pest \\
\hline & \multirow{12}{*}{ Hymenoptera } & Formicidae & - & 712 & beneficial \\
\hline & & \multirow{2}{*}{ Braconidae } & - & 23 & beneficial \\
\hline & & & Aphidius sp. & 14 & beneficial \\
\hline & & Vespidae & Vespa sp. Linnaeus, 1758 & 4 & beneficial \\
\hline & & \multirow{2}{*}{ Apidae } & Bombus sp. Latreille, 1802 & 1 & beneficial \\
\hline & & & Apis mellifera Linnaeus, 1758 & 7 & beneficial \\
\hline & & Ichneumonidae & - & 2 & beneficial \\
\hline & & Dryinidae & - & 10 & beneficial \\
\hline & & Eulophidae & - & 18 & beneficial \\
\hline & & Mymaridae & - & 4 & beneficial \\
\hline & & Platygastridae & Platygaster sp. & 11 & beneficial \\
\hline & & Crabronidae & - & 1 & beneficial \\
\hline & \multirow{7}{*}{ Diptera } & \multirow{2}{*}{ Muscidae } & Musca sp. Linnaeus, 1758 & 181 & indifferent \\
\hline & & & Hydrotaea sp. Robineau-Desvoidy, 1830 & 70 & indifferent \\
\hline & & Sciaridae & - & 194 & pest \\
\hline & & Phoridae & - & 8 & pest \\
\hline & & Empididae & - & 6 & beneficial \\
\hline & & Simulidae & - & 3 & indifferent \\
\hline & & Sphaeroceridae & - & 1 & pest \\
\hline
\end{tabular}


Table 2. Cont.

\begin{tabular}{|c|c|c|c|c|c|}
\hline Class & Order & Family & Genus/Species & In Total & Category \\
\hline & & Trichoceridae & - & 2 & pest \\
\hline & & Tabanidae & - & 1 & pest \\
\hline & Mecoptera & Panorpidae & Panorpa sp. Linnaeus, 1758 & 2 & indifferent \\
\hline & Lepidoptera & - & - & 1 & pest \\
\hline Arachnida & - & - & - & 3111 & beneficial \\
\hline Malacostraca & Isopoda & - & - & 250 & indifferent \\
\hline Diplopoda & - & - & - & 82 & indifferent \\
\hline Chilopoda & - & - & - & 10 & beneficial \\
\hline Gastropoda & - & - & - & 10 & indifferent \\
\hline
\end{tabular}

The composition of soil fauna, according to the influence of organisms on agriculture, consists of 6601 members of beneficial fauna, which is $84 \%$ of the total fauna collected, 603 members were pests, which is $8 \%$ of the total fauna collected, and 632 members were indifferent fauna, which is $8 \%$ of the total fauna collected. In our study, out of the total beneficial fauna which comprised 6601 individuals, 3111 individuals were spiders, which is $47 \%$ of the total beneficial fauna collected. This confirms the findings of Costello and Daane [37], Pearce et al. [38] and Pajač Živković et al. [39], in which they stated that spiders are among the most abundant predators in the soil layer and in large numbers can play an important role in reducing the pest population.

\subsection{Dominance and Frequency of Collected Fauna}

After determination, the parameters of dominance and frequency of classes and orders per total number of collected soil fauna were calculated. According to the dominance index, the classes Arachnida and Insecta (and individually the orders Hymenoptera and Coleoptera) were classified as eudominant. The results show that the class Insecta accounted for $56 \%$ and the class Arachnida for $40 \%$ of the total number of fauna collected. Within the class Insecta, the order Coleoptera accounts for $34 \%$ of the total number of fauna collected and the order Hymenoptera accounts for only $10 \%$ of the total number of fauna collected. The order Diptera is classified as the dominant order and accounts for $6 \%$ of the total number of fauna collected, and the order Collembola as the sub-dominant order accounts for only $3 \%$ of the total number of fauna collected. The frequency index of these orders over all the samples shows that the orders Coleoptera (100\%), Hymenoptera (89\%), Diptera (92\%) and the class Arachnida (100\%) belong to the category of euconstants, with their frequency index occurring in more than $75 \%$ of the samples. The order Collembola (25\%) belongs to the category of accessory orders, occurring in $25 \%$ of the samples.

When the same parameters were analysed by collection period, the dominance index of the members of the order Coleoptera was 34\%, 58\% and $21 \%$, respectively; it was classified as the eudominant order in all three collection periods. However, the results showed that its dominance increased in June and decreased in September. Members of the class Arachnida were also classified as a eudominant order throughout the collection period, with a dominance index of 42\% (April), 20\% (June) and 32\% (September). The results show that their index decreased in June and increased in September, which was the opposite to the members of the order Coleoptera. The order Diptera is classified as a eudominant order in April with a dominance index of 11\%, while in June and September it is classified as a dominant order with a dominance index of $8 \%$ and $10 \%$, respectively. Members of the order Hymenoptera increased in each sampling period and were classified as a subdominant order with a dominance index of 5\% in April, dominant order with a dominance index of $6 \%$ in June and eudominant order with a dominance index of $23 \%$ in September. Members of the order Hemiptera also increased in their dominance index over 
the study period. In April, it was classified as a recurrent order with a dominance index of $1 \%$, and in June and September it was classified as a subdominant order with dominance indices of $1 \%$ and $4 \%$, respectively. The order Isopoda was subdominant in April with a dominance index of $3 \%$, then fell to a recedent order in June with a dominance index of $1 \%$, and rose to a dominant order in September with a dominance index of $5 \%$.

The class Arachnida (100\%) and, within the class Insecta, the order Coleoptera $(100 \%)$ are classified as euconstant throughout the sampling period and occur in all samples collected. The order Diptera is also classified as euconstant throughout April and September and was found in every sample collected, while in June it occurs in $75 \%$ of the samples. The order Hymenoptera is found in all the collected samples in April and September and is classified as a euconstant order, while in June it is found in $67 \%$ and is classified as a constant order. Members of the order Hemiptera were present in all collected samples in April and classified as a euconstant order, in June they were classified as an accessory order and were present in $33 \%$ of collected samples, while in September they were again classified as a euconstant order and were present in $83 \%$ of collected samples. The order Isopoda was found in $67 \%$ of the collected samples in April, in $50 \%$ of the collected samples in September and was classified as a constant order, and in June it was found as an accessory order in only $17 \%$ of the collected samples.

\subsection{Influence of Pre-Sowing Tillage on Soil Fauna Abundance}

The total number of catches from the same pre-seeding measures was tested mutually and the $p$ values ranged from 0.158978 to 0.687678 , which means that the same pre-seeding measure had no influence on the abundance of fauna on the tested sites in the Šašinovec area. Therefore, in the further results, we present summarised data on collected soybean fauna per measure before sowing.

Table 3 shows the results of ANOVA between the total number of catches of all soildwelling fauna on the studied variants throughout the survey period. The results show that catches were extremely high in April and that they decreased during the summer and autumn months. In April, significantly more members of the fauna were found in fields with glyphosate and in fields where mulching was carried out. The lowest abundance of fauna was found in fields with cover crops prior to seeding. In June, up to 10 times lower catches of fauna were found, and significantly the highest catches were found in fields where ploughing was carried out before sowing, and the lowest catches were found in fields with mulching, glyphosate and standard tillage. In September, catches were even lower and no differences were found between the studied variants.

Table 3. Total catches of soil fauna ( \pm standard error: SE) on all variants throughout the research period.

\begin{tabular}{cccc}
\hline \multirow{2}{*}{ Pre-Sowing Activity } & \multicolumn{3}{c}{ Research Period } \\
\cline { 2 - 4 } & April & June & September \\
\cline { 2 - 4 } & $199.5 \pm 10.8^{\mathrm{c}, *}$ & $27.8 \pm 3.5^{\mathrm{b}, \mathrm{c}}$ & $21.5 \pm 7.1^{\mathrm{ns}}$ \\
Cover plants & $453.0^{\mathrm{a}} \pm 33.8^{\mathrm{a}}$ & $25.3 \pm 2.8^{\mathrm{c}}$ & $19.5 \pm 7.2^{\mathrm{ns}}$ \\
Mulching & $287.5 \pm 51.5^{\mathrm{b}, \mathrm{c}}$ & $49.8 \pm 2.7^{\mathrm{a}}$ & $10.0 \pm 1.1^{\mathrm{ns}}$ \\
Ploughing & $460.8 \pm 24.2^{\mathrm{a}}$ & $21.5 \pm 2.7^{\mathrm{c}}$ & $28.0 \pm 4.8^{\mathrm{ns}}$ \\
Glyphosate & $249.0^{\mathrm{a}} \pm 24.8^{\mathrm{c}}$ & $42.8^{\mathrm{c}} \pm 4.5^{\mathrm{a}, \mathrm{b}}$ & $16.0 \pm 2.6^{\mathrm{ns}}$ \\
Undermining & $404.0 \pm 32.0^{\mathrm{a}, \mathrm{b}}$ & $18.3 \pm 1.6^{\mathrm{c}}$ & $28.5 \pm 7.2^{\mathrm{ns}}$ \\
Standard & 147.75 & 15.26 & $\mathrm{~ns}$ \\
\hline Tukey's HSD $p=0.05^{* *}$ & 64.3 & 6.6 & 11.0 \\
\hline Standard Deviation & 1.8 & 0.6 & 23.5 \\
\hline Levene's F & 0.156 & 0.702 & $0.001^{*}$
\end{tabular}

* values marked with the same letter $\left(^{\mathrm{a}-\mathrm{c}}\right)$ do not differ significantly $(p>0.05$; HSD test); ns-non significant;

** HSD was determined by comparing the total abundance of fauna between different methods of pre-sowing tillage in all periods of research. Equality of variances was tested with Levene's test and reaches with equal variances $(p>0.05) ; ' t=$ Mean descriptions are reported in transformed data units and are not de-transformed (data were $\log (x+1)$ transformed and arcsin trans-formed $\sqrt{ } x$ ). 
In April, a total of 6838 individuals of soil fauna were identified, representing $87 \%$ of the total catch. In June, 508 individuals of fauna were identified (6\%), and in September, 490 individuals $(6 \%)$ (Table 4$)$.

Table 4. Abundance of the total soil-dwelling fauna in all variants during investigation period.

\begin{tabular}{cccccccc}
\hline \multirow{2}{*}{$\begin{array}{c}\text { Sampling } \\
\text { Period }\end{array}$} & \multicolumn{7}{c}{ Interventions Prior to Soybean Sowing } \\
\cline { 2 - 8 } & Cover Plants & Mulching & Ploughing & Glyphosate & Undermining & Standard & TOTAL \\
\hline April & 676 & 1533 & 1013 & 1526 & 815 & 1275 & 6838 \\
\hline June & 86 & 73 & 119 & 60 & 122 & 48 & 508 \\
\hline September & 94 & 71 & 45 & 103 & 68 & 109 & 490 \\
\hline TOTAL & 856 & 1677 & 1177 & 1689 & 1005 & 1432 \\
\hline
\end{tabular}

Soybean soil-dwelling fauna is many times more numerous in the spring months (the onset of soybean vegetation), while it drastically decreases later. Nait-Kaci et al. [40] claim that a large difference in research results during the year is due to the sensitivity of terrestrial fauna to climatic conditions, especially heat and humidity, and the influence of vegetation cover. There are numerous studies that also find the highest abundance of fauna in spring months [41], which is probably due to more favourable climatic conditions (more humidity, lower temperatures). Gkisakis et al. [42] conducted a study on soil fauna in common and hilly olive groves and the results showed the highest number of individuals in spring, while in summer and autumn the number decreases. Goncalves et al. [43] in their study on soil fauna in olive groves found that most of the soil fauna was collected in spring. House and All [44] in their study also found the highest numbers of members of the order Coleoptera in pitfall traps in mid-spring in soybean cultivation.

In April, most fauna was collected in the field where mulching was performed and in the field where glyphosate was applied. The percentage of fauna in both fields was $22 \%$. Fields with standard tillage had $19 \%$ of the fauna, while fields that were ploughed had $15 \%$ of the total fauna. Fields with undermining had $12 \%$ of the total fauna. Fields with cover crops had the least amount of fauna, only 10\%. In June, the most fauna was collected in the field with undermining and the field with ploughing, with percentages of total fauna of $25 \%$ and $23 \%$, respectively. In the fields with cover crops, the proportion of fauna was $17 \%$. In the fields with mulching, the proportion was $14 \%$, and in the fields with glyphosate application, the proportion was $12 \%$ of the total catches. The lowest proportion of fauna was found in the fields with standard tillage, only $10 \%$ of the total catch. In September, the most fauna was collected in fields with standard tillage and glyphosate application, $22 \%$ and $21 \%$, respectively. In fields with cover crops, the percentage of fauna was $19 \%$. Fields with mulching and undermining had similar percentages, 15 and 14\%, respectively. The lowest percentage of fauna was found in the field with ploughing, only $9 \%$ of the total catch. As reported by several authors, the associated conserved management systems contribute to the optimal development of soil fauna, besides the high relationship with soil fertility due to increased biological activity [45-47]. In contrast, the no-till measures showed a lower occurrence and diversity of soil organisms. Therefore, the conserved soil management should not be recommended when the objective is to benefit and to preserve soil biodiversity, regardless of the type of soil tillage and management.

The total catches of various members of the soybean soil fauna classified into orders/classes were analysed during the study period to determine differences among fields within each taxonomic category with respect to the sampling period. The detailed analysis of the number of individuals from different statistical categories collected in April, June and September on different tillage systems is presented in Tables 5-7.

There were no significant differences in the number of individuals captured in April between different tillage systems in the orders Orthoptera, Hemiptera, and the classes Arachnida and Diplopoda. The differences were found in the orders Colembolla, Coleoptera, 
Hymenoptera, Diptera and the class Malacostraca. Among the fields with different tillage methods, significantly higher catch of individuals of order Coleoptera was recorded in the fields with mulching. In fields with ploughing, a significantly higher number of members of order Hymenoptera was recorded. In the fields with glyphosate, significantly higher catches of individuals of the orders Colembolla and the class Malacostraca were recorded. However, the catches of individuals of the classes Malacostraca were very low. Members of the class Arachnida were caught in high numbers in all fields, but due to high variability in catches, differences between fields with different tillage practices were not detected.

Table 5. Total soil fauna analysed by order/class $( \pm S E)$ collected in April on different tillage systems before sowing.

\begin{tabular}{|c|c|c|c|c|c|c|c|c|c|}
\hline $\begin{array}{l}\text { Pre-Sowing } \\
\text { Activity }\end{array}$ & $\begin{array}{l}\frac{\pi}{0} \\
\stackrel{0}{0} \\
\stackrel{0}{0}\end{array}$ & 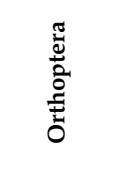 & 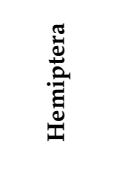 & $\begin{array}{l}\frac{\pi}{0} \\
\frac{\tilde{a}}{0} \\
\frac{0}{0}\end{array}$ & 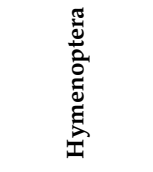 & $\begin{array}{l}\frac{a}{2} \\
\stackrel{0}{0}\end{array}$ & 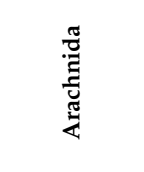 & 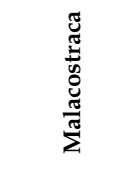 & 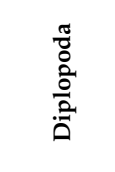 \\
\hline Cover plants & $14 \pm 3.5^{\mathrm{b}, \mathrm{z}}$ & $1 \pm 0.7$ & $1.9 \pm 0.1$ & $61.5 \pm 0^{\mathrm{b}}$ & $21.8 \pm 7.5^{b}$ & $4.1 \pm 0.1^{b}$ & $60.1 \pm 0$ & $0 \pm 0^{c}$ & $0.8 \pm 0.3$ \\
\hline Mulching & $9.8 \pm 5.6^{b}$ & $3.3 \pm 0.3$ & $2.7 \pm 0.1$ & $146.9 \pm 0.1^{\mathrm{a}}$ & $28.6 \pm 2.1^{a, b}$ & $14.2 \pm 0.1^{\mathrm{a}, \mathrm{b}}$ & $149.7 \pm 0.1$ & $5.8 \pm 0.1^{\mathrm{b}}$ & $1.5 \pm 0.5$ \\
\hline Ploughing & $0 \pm 0^{\mathrm{b}}$ & $3 \pm 1.1$ & $2.6 \pm 0.2$ & $79.6 \pm 0.1^{\mathrm{a}, \mathrm{b}}$ & $63.1 \pm 6.8^{a}$ & $5.3 \pm 0.2^{\mathrm{a}, \mathrm{b}}$ & $66.8 \pm 0.1$ & $0.6 \pm 0.1^{\mathrm{c}}$ & $11.8 \pm 6.6$ \\
\hline Glyphosate & $29.8 \pm 1.8^{\mathrm{a}}$ & $2.5 \pm 1$ & $2.9 \pm 0.2$ & $105.4 \pm 0^{\mathrm{a}, \mathrm{b}}$ & $13.6 \pm 3^{b}$ & $8.5 \pm 0.1^{\mathrm{a}, \mathrm{b}}$ & $150.2 \pm 0.1$ & $35.4 \pm 0.1^{\mathrm{a}}$ & $2 \pm 0.7$ \\
\hline Undermining & $6.3 \pm 1.7^{b}$ & $1 \pm 0.6$ & $2.2 \pm 0.3$ & $70.4 \pm 0.1^{b}$ & $23 \pm 2.1^{b}$ & $5.9 \pm 0.1^{\mathrm{a}, \mathrm{b}}$ & $82.8 \pm 0.1$ & $0.2 \pm 0.1^{c}$ & $1 \pm 0.4$ \\
\hline Standard & $0 \pm 0^{\mathrm{b}}$ & $1 \pm 0.4$ & $1.7 \pm 0.1$ & $117.9 \pm 0.1^{\mathrm{a}, \mathrm{b}}$ & $25.4 \pm 5.4^{\mathrm{b}}$ & $20.7 \pm 0.2^{\mathrm{a}}$ & $151 \pm 0.1$ & $5.9 \pm 0.1^{b}$ & $1.3 \pm 0.8$ \\
\hline $\begin{array}{c}\text { Tukey's HSD } \\
p=0.05^{* *}\end{array}$ & 14.4 & ns & ns & 58.56 & 33.65 & 14.96 & ns & 2.81 & ns \\
\hline $\begin{array}{l}\text { Standard } \\
\text { Deviation }\end{array}$ & 6.2 & 1.22 & $0.39 t$ & $0.12 \mathrm{t}$ & $9.48 \mathrm{t}$ & $0.26 \mathrm{t}$ & $0.18 \mathrm{t}$ & $0.23 \mathrm{t}$ & 1.15 \\
\hline Levene's F & $\begin{array}{c}33.1 \\
0.001\end{array}$ & $\begin{array}{c}1.3 \\
0.32\end{array}$ & $\begin{array}{c}1.2 \\
0.34\end{array}$ & $\begin{array}{c}0.4 \\
0.84\end{array}$ & $\begin{array}{c}2.4 \\
0.08\end{array}$ & $\begin{array}{c}2.8 \\
0.045 \text { * }\end{array}$ & $\begin{array}{c}2.5 \\
0.06\end{array}$ & $\begin{array}{c}5.5 \\
0.003\end{array}$ * & $\begin{array}{c}1.2 \\
0.35\end{array}$ \\
\hline
\end{tabular}

${ }^{¥}$ values marked with the same letter $\left({ }^{\mathrm{a}-\mathrm{c}}\right)$ do not differ significantly $\left(p>0.05\right.$; HSD test); ns-non significant value; ${ }^{*}$ significant value; ${ }^{* *}$ HSD was determined by comparing the numbers of each group of insects between different methods of pre-sowing tillage; Equality of variances was tested with Levene's test and reaches with equal variances $(p>0.05)$; ' $t=$ Mean descriptions are reported in transformed data units and are not de-transformed (data were $\log (x+1)$ transformed and arcsin transformed $\sqrt{ } x)$.

The results in Table 6 show that there were no significant differences in catches between the variants in the orders Collembola, Orthoptera, Hemiptera, Hymenoptera, Diptera and the class Diplopoda in June. The only differences in catches were found in the order Coleoptera and the classes Arachnida and Malacostraca. Members of the order Coleoptera were significantly more abundant in fields with ploughing and undermining. Catches in other fields were low and did not differ significantly. Members of the class Arachnida were caught in fields with cover crops, ploughing and undermining. There were no significant catches in other fields. The Malacostraca class had the significantly highest catch in fields with glyphosate, but it should be noted that these catches were very small. 
Table 6. Total soil fauna analysed by order/class $( \pm \mathrm{SE})$ collected in June on different tillage systems before sowing.

\begin{tabular}{|c|c|c|c|c|c|c|c|c|c|}
\hline $\begin{array}{c}\text { Pre-Sowing } \\
\text { Activity }\end{array}$ & $\begin{array}{l}\frac{\pi}{0} \\
\frac{0}{0} \\
\overline{0} \\
0 \\
0\end{array}$ & 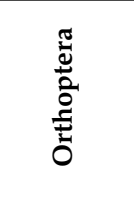 & 总 & 苞 & 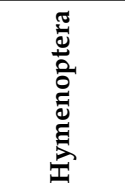 & 营 & 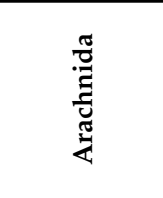 & 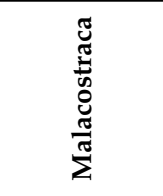 & $\begin{array}{l}\frac{\pi}{0} \\
0 \\
0 \\
\frac{0}{0} \\
\frac{0}{0}\end{array}$ \\
\hline Cover plants & $0 \pm 0$ & $0.4 \pm 2.1$ & $0 \pm 0$ & $9.4 \pm 0^{b, ¥}$ & $2.4 \pm 3.1$ & $0.4 \pm 0.2$ & $7.1 \pm 0.1^{\mathrm{a}}$ & $0 \pm 0^{b}$ & $0 \pm 0$ \\
\hline Mulching & $0 \pm 0$ & $2 \pm 2.9$ & $0.2 \pm 0.1$ & $8.5 \pm 0.1^{b}$ & $0.1 \pm 1.4$ & $1.7 \pm 0.3$ & $2.3 \pm 0.1^{\mathrm{a}, \mathrm{b}}$ & $0 \pm 0^{\mathrm{b}}$ & $0 \pm 0$ \\
\hline Ploughing & $0 \pm 0$ & $0.1 \pm 2$ & $0.4 \pm 0.2$ & $24.3 \pm 0^{\mathrm{a}}$ & $1.6 \pm 2.7$ & $0.4 \pm 0.1$ & $4.9 \pm 0.2^{\mathrm{a}}$ & $0.2 \pm 0.1^{\mathrm{a}, \mathrm{b}}$ & $0 \pm 0$ \\
\hline Glyphosate & $0 \pm 0$ & $0.9 \pm 1.9$ & $0.2 \pm 0.1$ & $7.7 \pm 0^{\mathrm{b}}$ & $0.1 \pm 2$ & $0.4 \pm 0.1$ & $3.2 \pm 0^{\mathrm{a}, \mathrm{b}}$ & $1.1 \pm 0.1^{\mathrm{a}}$ & $0 \pm 0$ \\
\hline Undermining & $0 \pm 0$ & $0.3 \pm 1.7$ & $0.4 \pm 0.2$ & $18.3 \pm 0.1^{\mathrm{a}}$ & $2.2 \pm 2.9$ & $1.2 \pm 0.2$ & $5.7 \pm 0^{\mathrm{a}}$ & $0 \pm 0^{\mathrm{b}}$ & $0 \pm 0$ \\
\hline Standard & $0 \pm 0$ & $0.3 \pm 1.7$ & $0.4 \pm 0.2$ & $8.6 \pm 0.1^{b}$ & $0.1 \pm 2$ & $0.9 \pm 0.1$ & $0.4 \pm 0.1^{b}$ & $0 \pm 0^{b}$ & $0 \pm 0$ \\
\hline $\begin{array}{c}\text { Tukey's HSD } \\
p=0.05^{* *}\end{array}$ & ns & ns & ns & 7.17 & ns & ns & 2.87 & 0.91 & ns \\
\hline $\begin{array}{l}\text { Standard } \\
\text { Deviation }\end{array}$ & 0 & $4.54 \mathrm{t}$ & $0.17 \mathrm{t}$ & $0.11 \mathrm{t}$ & $5.24 \mathrm{t}$ & $0.30 \mathrm{t}$ & $0.21 \mathrm{t}$ & $0.11 \mathrm{t}$ & 0.24 \\
\hline \multirow{2}{*}{ Levene's F } & & 0.29 & 0.25 & 0.95 & 0.24 & 1.68 & 26.8 & 2.4 & \\
\hline & & 0.91 & 0.93 & 0.47 & 0.94 & 0.19 & $0.001 *$ & 0.07 & \\
\hline
\end{tabular}

${ }^{¥}$ values marked with the same letter $\left({ }^{(a, b}\right)$ do not differ significantly $\left(~ p>0.05\right.$; HSD test); ns—non significant value; ${ }^{*}$ significant value; ${ }^{* *}$ HSD was determined by comparing the numbers of each group of insects between different methods of pre-sowing tillage; Equality of variances was tested with Levene's test and reaches with equal variances $(p>0.05)$; 't $=$ Mean descriptions are reported in transformed data units and are not de-transformed (data were $\log (x+1)$ transformed and arcsin transformed $\sqrt{ } x$ ).

The results in Table 7 show that in September the number of members of the orders Collembola, Orthoptera, Hemiptera, Coleoptera, Hymenoptera, Diptera and the classes Malacostraca and Chilopoda did not differ significantly among the variants of the study. Only in the class Arachnida were differences in catches found between the variants studied. The number of members of the class Arachnida was significantly higher in fields with glyphosate and slightly lower in fields with cover crops, mulching and standard tillage. Statistically, the lowest catches were found in fields where ploughing and undermining were used.

Table 7. Total soil fauna analysed by order/class $( \pm S E)$ collected in September on different tillage systems before sowing.

\begin{tabular}{|c|c|c|c|c|c|c|c|c|c|}
\hline $\begin{array}{c}\text { Pre-Sowing } \\
\text { Activity }\end{array}$ & $\begin{array}{l}\frac{\pi}{0} \\
0 \\
\stackrel{0}{0} \\
\frac{0}{0}\end{array}$ & 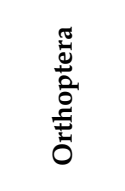 & 营 & $\frac{\pi}{\stackrel{0}{0}}$ & 旁 & 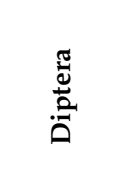 & 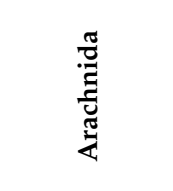 & 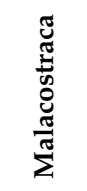 & $\begin{array}{l}\frac{\pi}{0} \\
0 \\
0 \\
\frac{0}{0} \\
\frac{0}{0}\end{array}$ \\
\hline Cover plants & $0 \pm 0$ & $0 \pm 0$ & $0.4 \pm 0.1$ & $4.3 \pm 0.1$ & $2.2 \pm 1$ & $3.9 \pm 0.2$ & $4.5 \pm 0.1^{\mathrm{a}, \mathrm{b}, \ngtr}$ & $0 \pm 0$ & $0.3 \pm 0.3$ \\
\hline Mulching & $0 \pm 0$ & $0 \pm 0$ & $0.7 \pm 0.1$ & $3 \pm 0.1$ & $0.7 \pm 1.7$ & $2.7 \pm 0.2$ & $5.7 \pm 0.2^{\mathrm{a}, \mathrm{b}}$ & $0 \pm 0$ & $0.3 \pm 0.3$ \\
\hline Ploughing & $0 \pm 0$ & $0.1 \pm 1.4$ & $0.4 \pm 0.1$ & $2.9 \pm 0$ & $0.7 \pm 1.7$ & $1.1 \pm 0.1$ & $2.5 \pm 0.1^{\mathrm{b}}$ & $0 \pm 0$ & $1.3 \pm 0.3$ \\
\hline Glyphosate & $0 \pm 0$ & $0 \pm 0$ & $0.7 \pm 0.1$ & $5 \pm 0$ & $1.4 \pm 2.6$ & $3.7 \pm 0.1$ & $12.4 \pm 0.1^{\mathrm{a}}$ & $0 \pm 0$ & $0 \pm 0$ \\
\hline Undermining & $0 \pm 0$ & $0.3 \pm 1.7$ & $0.2 \pm 0.1$ & $2.7 \pm 0.1$ & $2.4 \pm 3.1$ & $5.7 \pm 0$ & $2.2 \pm 0.1^{b}$ & $0 \pm 0$ & $0 \pm 0$ \\
\hline Standard & $0 \pm 0$ & $0 \pm 0$ & $2.1 \pm 0.4$ & $4.2 \pm 0.2$ & $2.9 \pm 1$ & $5.3 \pm 0.2$ & $7 \pm 0.2^{a, b}$ & $0 \pm 0$ & $0.5 \pm 0.3$ \\
\hline $\begin{array}{c}\text { Tukey's HSD } \\
p=0.05^{* *}\end{array}$ & ns & ns & ns & ns & ns & ns & 8.84 & ns & ns \\
\hline $\begin{array}{l}\text { Standard } \\
\text { Deviation }\end{array}$ & 0 & $1.68 \mathrm{t}$ & $0.36 \mathrm{t}$ & $0.18 \mathrm{t}$ & $3.86 \mathrm{t}$ & $0.31 \mathrm{t}$ & $0.25 \mathrm{t}$ & 0 & 0.42 \\
\hline Levene's F & & $\begin{array}{c}4.2 \\
0.01 \text { * }\end{array}$ & $\begin{array}{c}3.5 \\
0.02 \text { * }\end{array}$ & $\begin{array}{c}26.8 \\
0.001\end{array}$ & $\begin{array}{c}0.6 \\
0.68\end{array}$ & $\begin{array}{c}10.7 \\
0.001 *\end{array}$ & $\begin{array}{c}4.5 \\
0.008 \text { * }\end{array}$ & & $\begin{array}{c}1.8 \\
0.19\end{array}$ \\
\hline
\end{tabular}

${ }^{*}$ values marked with the same letter $\left({ }^{a, b}\right)$ do not differ significantly $\left(p>0.05 ;\right.$ HSD test); ns-non significant value; ${ }^{*}$ significant value; ${ }^{* *}$ HSD was determined by comparing the numbers of each group of insects between different methods of pre-sowing tillage; Equality of variances was tested with Levene's test and reaches with equal variances $(p>0.05) ; ' t=$ Mean descriptions are reported in transformed data units and are not de-transformed (data were $\log (x+1)$ transformed and $\arcsin$ transformed $\sqrt{ } x)$.

As shown in our results, beetles (Coleoptera: 2709) and spiders (Arachnida: 3072) are the most important members of the soil-dwelling fauna and, contrary to the statements of Wardle [48] that they are greatly reduced by tillage, we found that these two groups are 
much more influenced by weather conditions (high abundance in spring, low in autumn) than by tillage. The results of the factorial analysis (Table 8) provide additional support for our conclusions. The number of individuals collected was significantly $(p>0.05 \%)$ influenced by the pre-sowing treatment $(\mathrm{HSD}=1.28)$ and by the period of sampling (HSD $=0.74)$, as well as by the order/class of individuals recorded (HSD =1.71), proving that the pre-sowing treatment (i.e., the type of tillage) is responsible for the number of different orders/classes of soil-dwelling fauna in soybean. The sampling period also influences the captures as well as the interaction between pre-sowing intervention and sampling date. The significant interaction $(p>0.05 \%)$ was present between all the three factors (pre-sowing intervention, sampling period and order/class of individuals recorded) for the number of individuals recorded.

Table 8. Factorial analysis of the total capture of different orders/classes of soil fauna.

\begin{tabular}{cccc}
\hline Source of Variation & df & $p$ & HSD \\
\hline Total & 971 & & \\
Rep & 5 & & \\
Pre-sowing intervention (A) & 5 & 0.0001 & 1.28 \\
Sampling period (B) & 2 & 0.0001 & 0.74 \\
A $\times$ B & 10 & 0.0001 & 2.72 \\
Order $/$ Class (C) & 8 & 0.0001 & 1.71 \\
A $\times$ C & 40 & 0.0001 & 3.44 \\
B $\times$ C & 16 & 0.0001 & 10.53 \\
A $\times$ B $\times$ C & 80 & 0.0001 & \\
Error & 805 & &
\end{tabular}

\subsection{Influence of Pre-Sowing Tillage on Soil Fauna Species Richness}

The diversity in six different pre-sowing treatments, calculated according to the Shannon diversity index $(\mathrm{H})$ and according to Shannon's equitability $(\mathrm{EH})$, is shown in Table 9. We can see from our results that the diversity and evenness in the fields from the standard pre-sowing treatment are much lower than in the fields from the treatments that disturb the soil less, such as cover crops, ploughing, undermining and mulching. At the same time, the difference in diversity and evenness between the standard treatment and the treatment with glyphosate is somewhat smaller. In the fields where the activities are less intensive, not only is there a greater number of species, but the individuals in the community are more evenly distributed among these species. In the fields with standard pre-sowing activities, there are 50 species, but the class Arachnidae accounts for $46 \%$ of the community and Staphylinidae, Carabus tibiscianus and Formicidae account for the other $22 \%$ of the community.

Table 9. Shannon diversity index $(\mathrm{H})$ and Shannon's equitability $(\mathrm{EH})$ of collected fauna in different pre-sowing treatments.

\begin{tabular}{ccccccc}
\hline & \multicolumn{5}{c}{ Pre-Sowing Activity } \\
\hline & Cover Plants & Mulching & Ploughing & Glyphosate & Undermining & Standard \\
\hline $\begin{array}{c}\text { Shannon diversity } \\
\text { index }(\mathrm{H})\end{array}$ & 2.583 & 2.619 & 2.575 & 2.319 & 2.538 & 2.202 \\
$\begin{array}{c}\text { Number of species } \\
\text { Shannon's } \\
\text { equitability }\left(\mathrm{E}_{\mathrm{H}}\right)\end{array}$ & 44 & 57 & 48 & 42 & 49 & 50 \\
\hline
\end{tabular}

Our results confirm an earlier study by Baretta et al. [49], in which it was shown that the members of Collembola, Araneae, Hymenoptera, Orthoptera, Grylloblattodea, Lepidoptera and the total abundance of soil fauna were related not only to specific tillage systems but also to weather conditions at the time of sampling. The same authors noted that no-till has a higher amount of organic matter in the surface layers and a higher moisture 
status of the soil, which promotes the formation of a suitable environment for a greater abundance and diversity of edaphic groups, especially Coleoptera and Isopoda [49]. This was partially confirmed in our study, especially in the spring sampling, where the greatest faunal diversity was found in variants with mulching and glyphosate treatments, which are without intervention in the soil layers.

\subsection{Influence of Pre-Sowing Treatments on the Carabid Population}

Of all the fauna recorded, the family Carabidae has received special attention because of its importance as predators of numerous pest species [50-52] and as indicators of anthropogenic impacts and agroecosystem quality [22,52-58]. Members of the family Carabidae accounted for $34 \%$ of the total fauna collected. A total of 21 species of carabids were identified in this study, with Carabus cancellatus tibiscinus (441 individuals), Poecilus cupreus (383 individuals), Brachinus psophia (181 individuals) and Harpalus distinguindes (105 individuals) standing out in numbers. Lemic et al. [57] reported a similar carabid community (26 species with 15 genera) in an intensively managed agricultural production. Carabids are considered as one of the most important natural enemies in soil and subsoil layers [59]. They are also used in numerous studies as bioindicators of climate change and the effects of agrochemicals on their habitats, and their abundance can indicate the level of pollution in an area [12,60-68].

Depending on the pre-sowing interventions (Figure 1), the abundance of carabids in April was the highest in fields where mulching was carried out (363 individuals: 22\%), followed by fields with glyphosate application (317 individuals: $20 \%$ ); fields with standard tillage (241 individuals: $15 \%$ ); fields with undermining (183 individuals: $11 \%)$; ploughing (161 individuals: 10\%); and the lowest abundance was observed in fields with cover crops (121 individuals: 8\%). In June, the total number of catches was much lower and the highest number of carabids was observed in the fields with ploughing (only 56 individuals, $4 \%$ ), while the number was even lower in the other variants. In September, the abundance of carabids was very low, with a maximum catch of 10 individuals identified in the field where glyphosate was applied.

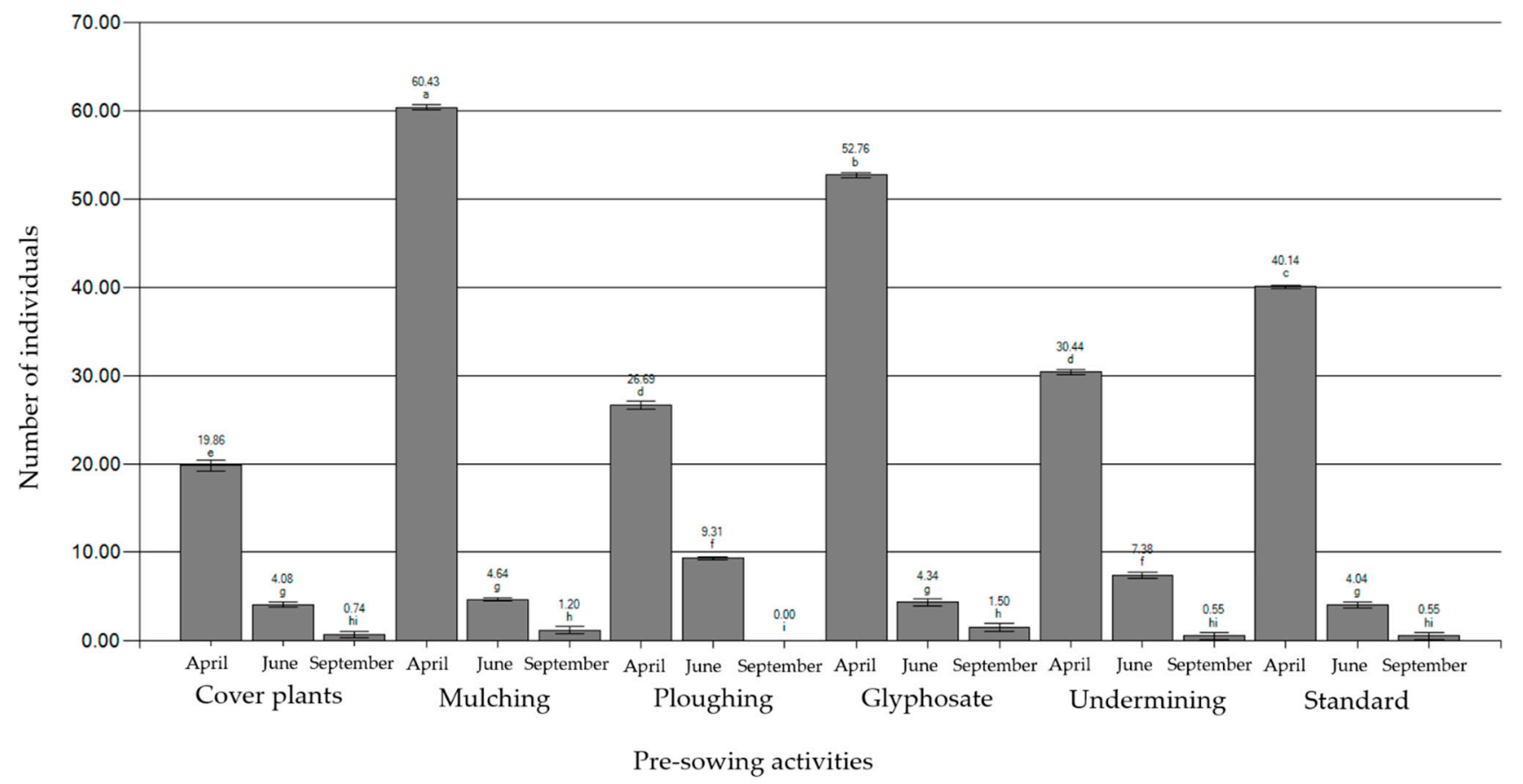

Figure 1. Number of members of the family Carabidae captured on fields with different pre-sowing interventions in the fields with different pre-sowing activities (values marked with the same letter do not differ significantly $(p>0.05$; HSD = 2.01)). 
Overall, the abundance of carabids was lowest in fields where ploughing and undermining occurred before soybeans were sown. This result is confirmed by the studies of Kromp (1999) [50] and Holland and Reynolds [60], who found that ploughing negatively affected the abundance of Carabidae. Numerous previous studies observed higher carabid catch rates in fields with reduced or no tillage compared to conventionally tilled fields [58,69-74].

Catches of collected individuals of the Carabidae family were significantly $(p>0.05 \%)$ affected by pre-sowing treatment $(\mathrm{HSD}=1.87)$ and sampling period $(\mathrm{HSD}=0.47)($ Table 10$)$. Pre-sowing treatment (i.e., tillage type) is responsible for the catch of Carabidae family members in soybean. At the same time, the highest catches were recorded in April, so the sampling period also has an effect on catch, as does the interaction between pre-sowing treatment and sampling date (HSD = 2.01). The highest abundance of ground beetles in Poland is in early spring (May) [64], which is consistent with our results of highest catches in April due to the shift in climatic conditions. Drmić et al. [75] found that endogenous ground beetle species are active throughout the growing season, which is probably due to the more stable conditions in the lower soil layers.

Table 10. Factorial analysis of the total capture of members of the family Carabidae.

\begin{tabular}{cccc}
\hline Source of Variation & df & $p$ & HSD \\
\hline Total & 107 & & \\
Rep & 5 & 0.0001 & 1.87 \\
Pre-sowing intervention (A) & 5 & 0.0001 & 0.47 \\
Sampling period (B) & 2 & 0.0001 & 2.01 \\
A $\times$ B & 10 & & \\
Error & 85 & & \\
\hline
\end{tabular}

Overall, the recorded members of the family Carabidae belong to 18 species and three genera, although individuals of the genera Amara sp., Bembidion sp. and Harpalus sp. were not identified to species level. The species richness of Carabidae was studied in Croatia in fields with maize [76,77], barley [78], sugar beet [79], rapeseed [80] and winter wheat [70], as well as in intensively cultivated fields [57]. The number of established species in their studies varied from eight [79] to 72 [80]. The reported studies focused on the dependence of faunal composition on different regions [76,77], crops [78,79], different cropping methods [78-80] and/or tillage practices [57]. In our study, the most numerous species were Carabus cancellatus tibiscinus, Poecilus cupreus and Brachinus psophia. Poecilus cupreus and Brachinus psophia are also mentioned as important and numerous species by other authors in their studies.

With this study, we obtained the results on the effects of pre-sowing interventions on the soil fauna of soybean, where climatic conditions and sampling time had an influence on the number and composition of the fauna studied. Multi-year studies are needed to obtain clearer data on the effects of treatment and other treatments (pesticides) on soil fauna abundance and composition. It appears that a reduction in mechanical activities in the shallow seed layer of the soil has a positive effect on species richness or biodiversity. Particularly noteworthy is the large proportion of natural enemies that currently colonise the study area, characterising the soil richness and stable natural equilibrium.

\section{Conclusions}

The composition of the soil fauna, according to the influence of the organisms on agriculture, is $84 \%$ beneficial fauna, $8 \%$ agricultural pests and $8 \%$ indifferent fauna. Overall, $47 \%$ of the total individuals of beneficial fauna collected were spiders, which are the most abundant predators in the soil layer and can play an important role in reducing pest population in large numbers. Bioindicator species such as ground beetles have not received much attention from researchers in Croatia, although they can indicate anthropogenically influenced field quality. In this study, we gained detailed knowledge about their community 
in a specific agricultural landscape in central Croatia. In modern agriculture, conservation programs are promoted to preserve useful species and biodiversity as a means to ensure sustainability.

The number of total fauna collected was influenced by the interaction between presowing intervention and sampling date. Pre-seeding interventions (such as cover crops, glyphosate application, and mulching) that did not involve soil activities did not affect the number and composition of soil fauna in the beginning of the vegetation. Mechanical intervention in the soil and warmer and drier weather (summer/fall) have a negative effect on the number and composition of soil fauna. As the season progresses, the influence of pre-sowing activities on soil fauna in soybean production decreases.

There are two main reasons for the difficulty in relating soil fauna activities to ecosystem and agricultural services: first, the top-down effects of management, especially in agricultural systems; second, the specificity of soil processes. In highly diverse communities, the abundance of specific soil fauna members' effects is masked by the other biotic events that contribute to the same properties and processes in soil (e.g., weather conditions. Many processes created by soil fauna (predation, symbiosis, mutualism, etc.) have dynamics that can nullify the signal of the soil intervention effects studied during one soybean season.

However, the results of this study contributed significantly to a better understanding of the baseline situation about soil fauna communities in an intensive agricultural landscape and will be a good starting point for future studies and conservation programs.

Author Contributions: Conceptualization, D.L. and M.P.; methodology, D.L. and R.B.; software, D.L.; validation, I.P.Ž., and R.B.; formal analysis, D.L. and M.P.; investigation, M.P.; resources, R.B.; data curation, M.P.; writing—original draft preparation, D.L., M.P. and I.P.Ž.; writing—review and editing, D.L. and I.P.Ž.; visualization, D.L. and I.P.Ž.; supervision, D.L. and R.B. All authors have read and agreed to the published version of the manuscript.

Funding: This research received no external funding.

Institutional Review Board Statement: Not applicable.

Informed Consent Statement: Not applicable.

Data Availability Statement: The datasets used and/or analysed during the current study are available from the corresponding author on reasonable request.

Acknowledgments: We thank Iva Dobrinčić, Matej Orešković, Marija Andrijana Galešić, Sandra Skendžić, Kristina Žganec and Maja Šupljika for help in the collection and determination of soil fauna. Special thanks to Josip Lakić for providing us soybean fields for this survey.

Conflicts of Interest: The authors declare no conflict of interest.

\section{References}

1. Filho, M.M.; Destro, D.; Miranda, A.L.; Spinosa, A.W.; Carrão-Panizzi, M.C.; Montalván, R. Relationships Among Oil Content, Protein Content and Seed Size in Soybeans. Braz. Arch. Biol. Technol. 2001, 44, 23-32. [CrossRef]

2. Alduk, H. Soybean Cultivation (Glycine max L. Merr.) on the Family Farm Alduk. Bachelor's Thesis, University Josip Juraj Strossmayer of Osijek, Osijek, Croatia, 27 September 2018.

3. Jurišić, M. AgBase-AgBase Handbook for Cropping I. Cropping System of More Important in Arable Crops; Gradska tiskara d.d. Osijek: Osijek, Croatia, 2008; p. 192.

4. Salaić, M. Soybean Cultivation on the Surfaces of "AGRO-TOVARNIK d.o.o" in the Period from 2010 to 2014 . Bachelor's Thesis, University Josip Juraj Strossmayer of Osijek, Osijek, Croatia, 2015.

5. Iannetta, P.P.M.; Young, M.; Bachinger, J.; Bergkvist, G.; Doltra, J.; Lopez-Bellido, R.J.; Monti, M.; Pappa, V.A.; Reckling, M.; Topp, C.F.E.; et al. A Comparative Nitrogen Balance and Productivity Analysis of Legume and Non-legume Supported Cropping Systems: The Potential Role of Biological Nitrogen Fixation. Front. Plant Sci. 2016, 7, 1700. [CrossRef]

6. Hrgović, S. Soybeans and Agrotechnics. Agrobiz/Agrosavjeti. 2021. Available online: https://www.agrobiz.hr/agrosavjeti/sojai-agrotehnika-939 (accessed on 3 August 2020).

7. Tsiafouli, M.A.; Thébault, E.; Sgardelis, S.P.; De Ruiter, P.C.; Van Der Putten, W.H.; Birkhofer, K.; Hemerik, L.; De Vries, F.T.; Bardgett, R.D.; Brady, M.V.; et al. Intensive agriculture reduces soil biodiversity across Europe. Glob. Chang. Biol. 2014, 21, 973-985. [CrossRef] 
8. Tillage, J.D. Selected teaching Material for Graduate Students—Plant Breeding. Osijek: Agricultural University. 2020. Available online: http:/ / www.fazos.unios.hr/upload/documents/01_Odabrani\%20tekstovi\%20iz\%20obrade\%20tla.pdf (accessed on 12 June 2020).

9. Cameron, E.K.; Martins, I.S.; Lavelle, P.; Mathieu, J.; Tedersoo, L.; Gottschall, F.; Guerra, C.A.; Hines, J.; Patoine, G.; Siebert, J.; et al. Global gaps in soil biodiversity data. Nat. Ecol. Evol. 2018, 2, 1042-1043. [CrossRef]

10. Delgado-Baquerizo, M.; Reich, P.B.; Trivedi, C.; Eldridge, D.J.; Abades, S.; Alfaro, F.D.; Bastida, F.; Berhe, A.A.; Cutler, N.A.; Gallardo, A.; et al. Multiple elements of soil biodiversity drive ecosystem functions across biomes. Nat. Ecol. Evol. 2020, 4, 210-220. [CrossRef]

11. van Capelle, C.; Schrader, S.; Brunotte, J. Tillage-induced changes in the functional diversity of soil biota: A review with a focus on German data. Eur. J. Soil Biol. 2012, 50, 165-181. [CrossRef]

12. Maceljski, M. Agricultural Entomology; Zrinski d.o.o.: Čakovec, Croatia, 2002; p. 17.

13. Lemić, D.; Gašparić, H.V.; Petrak, I.; Graša, Ž.; Bažok, R. Four-year arable crop rotation impact on beneficial soil surface arthropod fauna restoration. J. Cent. Eur. Agric. 2016, 17, 1346-1359. [CrossRef]

14. Duvnjak, L. Importance of Living Organisms in Soil, Ministry of Agriculture, Directorate for Professional Support of Agriculture and Fisheries Development. 2020. Available online: https:/ /www.savjetodavna.hr/2019/05/08/vaznost-zivih-organizama-utlu/ (accessed on 20 August 2020).

15. Heinrichs, E.A.; Muniappan, R. Integrated pest management for tropical crops: Soyabeans. CAB Rev. 2018, 13, 1-44. [CrossRef]

16. Edwards, C.A.; Thompson, A.R. Pesticides and the soil fauna. In Residue Reviews; Gunther, F.A., Gunther, J.D., Eds.; Springer: New York, NY, USA, 1973; Volume 45, pp. 1-79.

17. Casabé, N.; Piola, L.; Fuchs, J.; Oneto, M.L.; Pamparato, L.; Basack, S.; Giménez, R.; Massaro, R.; Papa, J.C.; Kesten, E. Ecotoxicological Assessment of the Effects of Glyphosate and Chlorpyrifos in an Argentine Soya Field. J. Soil. Sediments 2007, 7, 232-239. [CrossRef]

18. Nietupski, M. Ground beetles (Coleoptera: Carabidae) occurring in apple orchards under different production systems. Prog. Plant. Prot. 2012, 52, 360-365.

19. Bažok, R.; Kos, T.; Drmić, Z. Importance of ground beetles (Coleoptera: Carabidae) for biological stability of agricultural habitat focus on cultivation of sugar beet. Glas. Biljn. Zašt. 2015, 15, 264-276.

20. Cassagne, N.; Bal-Serin, M.-C.; Gers, C.; Gauquelin, T. Changes in humus properties and collembolan communities following the replanting of beech forests with spruce. Pedobiology 2004, 48, 267-276. [CrossRef]

21. Fiera, C. Biodiversity of Collembola in urban soils and their use as bioindicators for pollution. Pesqui. Agropecu. Bras. 2009, 44, 868-873. [CrossRef]

22. Rainio, J.; Niemelä, J. Ground beetles (Coleoptera: Carabidae) as bioindicators. Biodivers. Conserv. 2003, 12, 487-506. [CrossRef]

23. Kovačić, M. Glyphosate-related spear fracture-Desirable or undesirable? Tehnol. Zabilješke Kem. Ind. 2019, 68, 557-558.

24. Ostojić, Z.; Brzoja, D.; Barić, K. Status, purpose and consumption of glyphosate in Croatia and the world. Glas. Biljn. Zašt. 2018, $18,531-541$.

25. Vandenberg, L.N.; Blumberg, B.; Antoniou, M.N.; Benbrook, C.M.; Carroll, L.; Colborn, T.; Everett, L.G.; Hansen, M.; Landrigan, P.J.; Lanphear, B.P.; et al. Is it time to reassess current safety standards for glyphosate-based herbicides? J. Epidemiol. Community Health 2017, 71, 613-618. [CrossRef] [PubMed]

26. Auber, L. Atlas des Coléoptères de France, Belgique, Suisse; TOM 1, Boubée: Paris, France, 1965; p. 249.

27. Schmidt, L. Insect Determination Tables. Handbook for Agronomists, Foresters and Biologists; Agricultural University, Home printing house of the University of Zagreb: Zagreb, Croatia, 1970; p. 258.

28. Bechyne, J. Welcher Käfer ist Das? Kosmos-Natürfuhrer: Stuttgart, Germany, 1974; p. 134.

29. Harde, K.W.; Severa, F. Der Kosmos Käferführer; Kosmos-Natürfuhrer: Stuttgart, Germany, 1984; p. 334.

30. Booth, R.G.; Cox, M.L.; Madge, R.B. IIE Guides to Insects of Importance to Man. 3. Coleoptera; CAB International Wallingford: London, UK, 1990; p. 384.

31. Freude, H.; Harde, K.W.; Lohse, G.A.; Klausnitzer, B. Die Käfer Mitteleuropas. II Band. Adephaga 1; Elsevier GmbH: München, Germany, 2006; p. 506.

32. Balarin, I. Fauna Heteroptere na Krmnim Leguminozama i Prirodnim Livadama u SR Hrvatskoj. Ph.D. Thesis, University of Zagreb, Zagreb, Croatia, 1974.

33. Gylling Data Management Inc. ARM 2019®GDM Software, Revision 2019.4, August 5, 2019 (B = 25105); Gylling Data Management Inc.: Brookings, SD, USA, 2019.

34. Spellerberg, I.F.; Fedor, P.J. A tribute to Claude Shannon (1916-2001) and a plea for more rigorous use of species richness, species diversity and the 'Shannon-Wiener' Index. Glob. Ecol. Biogeogr. 2003, 12, 177-179. [CrossRef]

35. TIEM. Diversity Indices: Shannon's H and E. 2021. Available online: http://www.tiem.utk.edu/ gross/bioed/bealsmodules/ shannonDI.html (accessed on 20 August 2020).

36. Bažok, R.; Čačija, M.; Gajger, A.; Kos, T. Arthropod Fauna Associated to Soybean in Croatia. In Soybean: Pest Resistance; El-Shemy, H., Ed.; InTech: London, UK, 2013.

37. Costello, M.J.; Daane, K.M. Abundance of spiders and insect predators on grapes in central California. J. Arachnol. 1999, 27, 531-538. 
38. Pearce, S.; Hebron, W.M.; Raven, R.J.; Zalucki, M.P.; Hassan, E. Spider fauna of soybean crops in south-east Queensland and their potential as predators of Helicoverpa spp. (Lepidoptera: Noctuidae). Aust. J. Entomol. 2004, 43, 57-65. [CrossRef]

39. Živković, I.P.; Lemic, D.; Samu, F.; Kos, T.; Barić, B. Spider communities affected by exclusion nets. Appl. Ecol. Environ. Res. 2019, 17, 879-887. [CrossRef]

40. Nait-Kaci, M.B.; Hedde, M.; Bourbia, S.M.; Derridj, A. Hierarchization of factors driving soil macrofauna in North Algeria groves. Biotechnol. Agron. Soc. Envir. 2014, 18, 11-18.

41. Mouhoubi, D.; Djenidi, R.; Bounechada, M. Contribution to the Study of Diversity, Distribution, and Abundance of Insect Fauna in Salt Wetlands of Setif Region, Algeria. Int. J. Zoöl. 2019, 2019, 1-11. [CrossRef]

42. Gkisakis, V.D.; Kollaros, D.; Kabourakis, E.M. Soil arthopod biodiversity in plain and hilly olive orchard agroecosystem, in Crete, Greece. Entomol. Hell. 2014, 23, 18-28. [CrossRef]

43. Gonçalves, M.F.; Pereira, J.A. Abundance and Diversity of Soil Arthropods in the Olive Grove Ecosystem. J. Insect Sci. 2012, 12, 1-14. [CrossRef]

44. House, G.J.; All, J.N. Carabid Beetles in Soybean Agroecosystems. Environ. Èntomol. 1981, 10, 194-196. [CrossRef]

45. Alves, M.; Vicente, S.; Pires, J.C.; Deisi Tatiani de, G.; Veronezi, J.A.; Baretta, D. Macrofauna do solo influenciada pelo uso de fertilizantes químicos e dejetos de suínos no Oeste do Estado de Santa Catarina. Rev. Bras. Ciênc. Solo 2008, 32, 589-598. [CrossRef]

46. Baretta, D.; Santos, C.P.J.; Mafra, L.A.; do Prado Wildner, L.; Miquelluti, J.D. Fauna edáfica avaliada por armadilhas de catação manual afetada pelo manejo do solo na região oeste catarinense. Rev. Ciênc. Agrovet. 2003, 2, 97-106.

47. Silva, R.F.; Aquino, A.M.; Mercante, F.M.; Guimares, M.F. Macrofauna invertebrada do solo sob diferentes sistemas de produção em latossolo da região do Cerrado. Pesqui. Agropecu. Bras. 2006, 41, 697-704. [CrossRef]

48. Wardle, D.A. Impacts of disturbance on detritus food web sin agro-ecosystems of contrasting tillage and weed management practices. In Advances in Ecological Research; Begon, M., Fitter, A.H., Eds.; Academic Press: New York, NY, USA, 1995; Volume 26, pp. 105-185.

49. Baretta, D.; Bartz, M.L.C.; Fachini, I.; Anselmi, R.; Zortéa, T.; Baretta, C.R.D.M. Soil fauna and its relation with environmental variables in soil management systems. Rev. Ciênc. Agrovet. 2014, 45, 871-879. [CrossRef]

50. Kromp, B. Carabid beetles in sustainable agriculture: A review on pest control efficacy, cultivation impacts and enhancement. Agric. Ecosyst. Environ. 1999, 74, 187-228. [CrossRef]

51. Lee, J.C.; Menalled, F.D.; Landis, D.A. Refuge habitats modify impact of insecticide disturbance on carabid beetle communities. J. Appl. Ecol. 2001, 38, 472-483. [CrossRef]

52. Da Matta, D.H.; Cividanes, F.J.; Da Silva, R.J.; Batista, M.N.; Otuka, A.K.; Correia, E.T.; De Matos, S.T.S. Feeding habits of Carabidae (Coleoptera) associated with herbaceous plants and the phenology of coloured cotton. Acta Sci. Agron. 2017, $39,135$. [CrossRef]

53. Cole, L.J.; I McCracken, D.; Dennis, P.; Downie, I.S.; Griffin, A.L.; Foster, G.N.; Murphy, K.J.; Waterhouse, A. Relationships between agricultural management and ecological groups of ground beetles (Coleoptera: Carabidae) on Scottish farmland. Agric. Ecosyst. Environ. 2002, 93, 323-336. [CrossRef]

54. O’Rourke, M.E.; Liebman, M.; Rice, M.E. Ground beetle (Coleoptera: Carabidae) assemblage in conventional and diversified crop rotation systems. Environ. Entomol. 2008, 37, 121-130. [CrossRef]

55. Avgın, S.S.; Luff, M.L. Ground beetles (Coleoptera: Carabidae) as bioindicators of human impact. Mun. Ent. Zool. 2010, 5 , 209-215.

56. Baranová, B.; Fazekašová, D.; Jászay, T.; Manko, P. Ground beetle (Coleoptera: Carabidae) community of arable land with different crops. Folia Faun. Slov. 2013, 18, 21-29.

57. Lemic, D.; Čačija, M.; Gašparić, V.H.; Drmić, Z.; Bažok, R.; Živković, P.I. The ground beetle (Coleoptera: Carabidae) community in an intensively managed agricultural landscape. Appl. Ecol. Environ. Res. 2017, 15, 661-674. [CrossRef]

58. Gašparić, V.H.; Drmić, Z.; Čačija, M.; Graša, Ž.; Petrak, I.; Bažok, R.; Lemic, D. Impact of environmental conditions and agrotechnical factors on ground beetle populations in arable crops. Appl. Ecol. Environ. Res. 2017, 15, 697-711. [CrossRef]

59. Holland, J.; Reynolds, C.J. The impact of soil cultivation on arthropod (Coleoptera and Araneae) emergence on arable land. Pedobiology 2003, 47, 181-191. [CrossRef]

60. Thiele, H.U. Carabid Beetles in Their Environment: A Study on Habitat Selection by Adaptations in Physiology and Behaviour; Springer: Berlin, Germany, 1977; p. 372.

61. Maelfait, J.P.; Desender, K. Possibilities of Short-term Carabid Sampling for Site Assessment Studies. In The Role of Ground Beetles in Ecological and Environmental Studies; Stork, N.E., Ed.; Intercept: Andower, UK, 1990; pp. 217-225.

62. Asteraki, E.J.; Hanks, C.B.; Clements, R.O. The impact of two insecticides on predatory ground beetles (Carabidae) in newly sown grass. Ann. Appl. Biol. 1992, 120, 25-39. [CrossRef]

63. Asteraki, E.J.; Hanks, C.B.; Clements, R.O. The influence of different types of grassland field margin on carabid beetle (Coleoptera: Carabidae) communities. Agric. Ecosyst. Environ. 1995, 54, 125-128. [CrossRef]

64. Blake, S.; Foster, G.N.; Fischer, G.E.J.; Ligertwood, G.L. Effects of management practices on the ground beetle faunas of newly established wildflower meadows in southern Scotland. Ann. Zool. Fenn. 1996, 33, 139-147.

65. Jeschke, P.; Nauen, R.; Schindler, M.; Elbert, A. Overview of the Status and Global Strategy for Neonicotinoids. J. Agric. Food Chem. 2011, 59, 2897-2908. [CrossRef] 
66. Szczepaniec, A.; Creary, S.F.; Laskowski, K.L.; Nyrop, J.P.; Raupp, M.J. Neonicotinoid insecticide imidacloprid causes out-breaks of spider mites on elm trees in urban landscapes. PLoS ONE 2011, 6, e20018. [CrossRef]

67. Varvara, M.; Chimisliu, C.; Šustek, Z. Distribution and abundance of Calosoma uropunctatum Herbst 1784. (Coleoptera: Carabidae) in some agricultural crops in Romania, 1977-2010. Olten. Stud. Comun. Ştiint. Nat. 2012, 28, 79-90.

68. Douglas, M.R.; Rohr, J.R.; Tooker, J.F. Neonicotinoid insecticide travels through a soil food chain, disrupting biological control of non-target pests and decreasing soya bean yield. J. Appl. Ecol. 2014, 52, 250-260. [CrossRef]

69. House, G.J.; Parmalee, R.W. Comparison of soil arthropods and earthworms from conventional and no-tillage agroecosystems. Soil Till. Res. 1985, 5, 351-360. [CrossRef]

70. Ferguson, H.J.; McPherson, R.M. Abundance and diversity of adult carabidae in four soybean cropping systems in Virginia. $J$. Èntomol. Sci. 1985, 20, 163-171. [CrossRef]

71. Stinner, B.R.; McCartney, D.A.; Van Doren, D.M., Jr. Soil and foliage arthropod communities in conventional, reduced and no-tillage corn (maize, Zea mays, L.) systems: A comparison after 20 years of continuous cropping. Soil Till. Res. 1988, 11, 147-158. [CrossRef]

72. Tonhasca, A. Carabid beetle assemblage under diversified agroecosystems. Entomol. Exp. Appl. 1993, 68, $279-285$.

73. Vician, V.; Svitok, M.; Kočik, K.; Stašiov, S. The influence of agricultural management on the structure of ground beetle (Coleoptera: Carabidae) assemblages. Biologia 2015, 70, 240-251. [CrossRef]

74. Kosewska, A. Conventional and non-inversion tillage systems as a factor causing changes in ground beetle (Col. Carabidae) assemblages in oilseed rape (Brassica napus) fields. Period. Biol. 2016, 118, 231-239. [CrossRef]

75. Drmic, Z.; Cacija, M.; Lemic, D. Endogaeic ground beetles fauna in oilseed rape field in Croatia. J. Central Eur. Agric. 2016, 17, 675-684. [CrossRef]

76. Bažok, R.; Kos, T.; Barčić, I.J.; Kolak, V.; Lazarević, B.; Čatić, A. Abundance and distribution of the ground beetles Pterostichus melanarius (Illiger, 1798) and Pseudoophonus rufipes (DeGeer, 1774) in corn fields in Croatia. Entomol. Croat. 2007, 11, 39-51.

77. Kos, T.; Bažok, R.; Barčić, I.J. Abundance and frequency of ground beetles in three maize fields in Croatia. J. Environ. Prot. Ecol. 2011, 12, 894-902.

78. Kos, T.; Bažok, R.; Kozina, A.; Šipraga, J.; Dragić, S.; Tičinović, A. Ground beetle (Carabidae) fauna at untreated and treated barley fields in Croatia. Pestic. Benef. Org. IOBC/wprs Bull. 2010, 55, 79-84.

79. Kos, T.; Bažok, R.; Drmić, Z.; Graša, Ž. Ground beetles (Coleoptera: Carabidae) in sugar beet fields as the base for conservation biological control. Insect Pathogens and Entomoparasitic Nematodes Biological Control: Its unique role in integrated and organic production. IOBC-WPRS Bull. 2013, 90, 353-357.

80. Čuljak, G.T.; Büchs, W.; Prescher, S.; Schmidt, L.; Sivčev, I.; Juran, I. Ground Beetle Diversity (Coleoptera: Carabidae) in Winter Oilseed Rape and Winter Wheat Fields in North-Western Croatia. Agric. Conspec. Sci. 2016, 81, 21-26. 